\title{
The Spaces of Dream:
}

\section{Lutosławski’s Modernist Heterotopias}

As Witold Lutosławski connoisseurs bask in the afterglow of the 2013 centenary celebrations of his life, music and cultural significance in Poland, the UK and elsewhere, it is instructive to recall that his music has not enjoyed an entirely positive reception - not least because the more negative strand of that reception may be one of the reasons why his music had hitherto fallen 'off the concert map'1 after his death in 1994. A small but significant critical subplot has questioned the quality of his major works. Its challenge has taken two main forms - torn halves of an underlying accusation of superficiality. Some critics have decried his music's logic, arguing that its sensuous thrills mask a lack of syntactical rigour, although recent scholarship has disputed these claims. ${ }^{2}$ Others have found his music deficient in profundity, contrasting what they hear as a veneer of complexity to a lack of symbolic depth. James Harley has articulated both sides of this view with challenging clarity. Arguing in the 2001 essay collection Lutosławski Studies that Lutosławski's post-tonal output, due to certain failings of its musical language, substituted expressive fireworks for more syntactically satisfying climaxes, Harley (parsing Terry Eagleton's The Ideology

${ }^{1}$ Fiona Maddocks, 'Lutoslawski [sic]: Orchestral Works III - review', 'The New Review', The Observer (18 November 2012), 27.

${ }^{2}$ See Nicholas Reyland, 'Lutosławski, "Akcja” and the Poetics of Musical Plot', Music \& Letters 88/4 (November 2007), 604-608 for a survey of this strand of Lutosławski reception plus an alternative perspective. 
of the Aesthetic) located late capitalism's 'fetishism of style and surface, its cult of hedonism and technique' within Lutosławski pieces, 'meant to gratify, not provoke'. ${ }^{3}$ Harrison Birtwistle put it rather more bluntly in a 1995 interview. Discussing the perceived difficulty of modern music - and responding to an interviewer's admission that his father had tried new music but could only get as far as Lutosławski - Birtwistle exclaimed, 'Well Lutosławki's easy! It's the acceptable face of modernism, isn't it? ${ }^{4}$

This essay begs to differ. For sure, the provocations of style and substance posed by Birtwistle's music - his modernism's acceptable unacceptability, as it were - certainly sound more properly modernist than the 'middlebrow' modernism of the Lutosławski depicted above. As Jonathan Cross documents, '[t]he primitivism of [Birtwistle's] music, its formality, its concern with ritualized, anti-narrative structures and with myth, its interest in rhythm and in constructing new kinds of temporality' are all facets of a compositional voice 'firmly rooted in early European modernism' ${ }^{5}$ Yet Birtwistle's and Harley's

${ }^{3}$ James Harley, 'Considerations of Symphonic Form in the Music of Witold Lutosławski', in Zbigniew Skowron, ed., Lutosławski Studies (Oxford: Oxford University Press, 2001), 192; citing Terry Eagleton, The Ideology of the Aesthetic (Oxford: Blackwell, 1990), 373.

${ }^{4}$ Dan Warburton, ‘Harrison Birtwistle', Paris Transatlantic Magazine (July 1995), http://www.paristransatlantic.com/magazine/interviews/birtwistle.html (accessed 24 April 2009).

${ }^{5}$ Jonathan Cross, Harrison Birtwistle: Man, Mind, Music (London: Faber \& Faber, 2000), 14. 
dismissals of Lutosławski entail assertions concerning the inauthenticity of Lutosławski's modernist style, and thus claims about the 'true' nature of musical modernism (including its implicit manifestation in Birtwistle's own music): one example of a familiar, now contested, story productively re-examined in recent scholarship, including work by Christopher Chowrimootoo. ${ }^{6}$

As Allan Moore has demonstrated through his extensive theorizing of authenticity in popular music, music's creators cannot inscribe their work with incontrovertible aesthetic markers of any kind of authenticity, whatever their intentions. ${ }^{7}$ Rather, designations of authenticity are negotiated via interacting processes of creation and criticism in which consumers, operating within a lively discourse on the very notion of authenticity in a particular musical tradition, ascribe or withhold the value-judgement 'authentic'. Coloured by 'crude hierarchies and oppositions', such tropes, Chowrimootoo reminds one, were central to 'modernist self-conceptions[,] ... their immediate reception, and the reception of contemporary culture more broadly' from the early twentieth century onward. ${ }^{8}$ Criticism along these lines alleging the inauthentic modernism of Lutosławski's music after the mid 1950s, when circumstances in Poland permitted his re-engagement with contemporary musical trends, might therefore

${ }^{6}$ See, for example, Christopher Chowrimootoo, 'Reviving the Middlebrow, or: Deconstructing Modernism from the Inside', Journal of the Royal Musical Association 139/1 (2014), 187-93.

${ }^{7}$ See especially Allan Moore, 'Authenticity as Authentication', Popular Music 21/2 (2002), 209-224.

${ }^{8}$ Chowrimootoo, 'Reviving the Middlebrow', 189. 
cite his pieces' many passages of consoling beauty (all those ravishing climactic aftermaths), his commitment to structural processes reimagining classicist conventions (such as his interest in plot, teleology and symphonic thought rather than anti-narrative re-imaginings of structure and temporality), his ideologically uncommitted adaptation of high modernist devices (note the limited in the composer's own description of his engagement with chance procedures, i.e., 'limited rhythmic aleatory'), or his failure rigorously to challenge audiences in some more suitably abrasive fashion.

Yet it simply does not follow that the expressive, structural or symbolic content of stylistically more approachable twentieth-century art works will necessarily be less provocative or authentically representative of the experience of modernity than more obviously challenging texts. As J. P. E. Harper-Scott has written on another composer with a distinct lack of modernist street cred,

[w]asn't [Elgar] a conservative, and doesn't that disallow modernism? That depends on whether one thinks new methods are necessary for communicating new thoughts - for instance that the only way to write a revolutionary manifesto is to use a computer. Yet older methods can often communicate modern sentiments with the same power as new ones... [l]t is the music's meaning, insofar as that can be grasped from a sensitive (but not necessarily technical) listening, that makes it modernist. ${ }^{9}$

9 J. P. E. Harper-Scott, Elgar: An Extraordinary Life (London: ABRSM, 2007), 8687. Harper-Scott radically expands his conception of modernism in The Quilting Points of Musical Modernism: Revolution, Reaction, and William Walton (Cambridge and New York: Cambridge University Press, 2012). 
While Harper-Scott is not arguing here for a simplistic separation of what music says from how it says it - in many cases, clearly, the medium is the message the notion that less straightforwardly authentic forms of modernism might arise in texts exhibiting a degree of tension between style and idea is provocative. The assumption 'accessible equals facile', anti-modernist, or merely more commercial, for instance, is not one that critics would make when examining, say, modern literature or visual art. Contrasting the formal complexities of certain recent novels to superficially more reactionary works, Gordon Burns has suggested (referencing Jonathan Franzen) that 'The day comes when the truly subversive literature is in some measure conservative. ${ }^{10}$ Similarly, when speaking of the representational yet provocative paintings of Paula Rego (and seeking to highlight a contrast to ostensibly more shocking modern art), Robert Hughes located Rego's integrity - her authenticity, as it were - in paintings telling stories whose very accessibility permitted her to '[test] the moral imagination'. ${ }^{11}$ More productive questions to ask of Lutosławski's music, then, and of his putative modernism, may be as follows: whose moral imaginations were these cultural texts designed to test, and what is the nature of the tests that are shaped by his musical narratives? Scholars of middlebrow literature, for instance, argue that such novels, by straddling 'the divide between the trashy romance or ${ }^{10}$ Gordon Burns, 'After the Flood', The Guardian (15 November 2003), http://www.guardian.co.uk/books/2003/nov/15/featuresreviews.guardianreview10 (accessed 24 April 2009).

${ }^{11}$ Hughes made this statement in BBC4's 'The New Shock of the New' (broadcast Friday 30 July 2004, 9.30pm-10.30pm, BBC4). 
thriller... and the philosophically or formally challenging novel', offer 'narrative excitement without guilt, and intellectual stimulation without undue effort. ${ }^{12}$ Can one pass Lutosławski's tests with similar ease? Or does his music, by straddling similar divides yet calling for significant effort leading to discomforting conclusions, fashion an example of Chowrimootoo's reconceptualized modernism: 'a space in which ambivalence and variety reigns, and boundaries ultimately disappear... challenging modernist historiography without necessarily writing over its history'? ${ }^{13}$

This essay proposes that Lutosławski posed tests of the moral imagination pertinent to Polish and wider Central-Eastern European experience during the mid to late twentieth century, not least through his musical staging of representational confrontations between the acceptably unacceptable face of modernity and the dangerous occupation of hope. A revisionist perspective on the authenticity of Lutosławski's modernism is thereby offered. In part, this is argued by relating his work to other twentieth-century music (including, it will turn out, Birtwistle's output). Crucially, however, it is also proposed by reconsidering the role of the more conventionally gratifying aspects of his pieces, plus the function of moments when his music fails syntactically to cohere, as something other than a cop out or shortcoming. One face of Lutosławski's Janus-like modernism makes a compelling but hitherto little acknowledged contribution to

${ }^{12}$ Nicola Humble, The Feminine Middlebrow Novel, 1920s to 1950s: Class, Domesticity, and Bohemianism (New York and Oxford: Oxford University Press, 2001), 11-12; quoted in Chowrimootoo, 'Reviving the Middlebrow', 191.

${ }^{13}$ Chowrimootoo, 'Reviving the Middlebrow', 192. 
music's exploration of what Fredric Jameson described as the 'grand modernist thematics of alienation, anomie, solitude, social fragmentation, and isolation. ${ }^{, 14}$ The other face of Lutosławski's modernism is not dystopian; yet neither is it utopian. Rather, to adapt a fertile idea from the writings of Michel Foucault, one can call it heterotopian. This essay's other main objective, therefore, is to demonstrate that fertility by interpreting as heterotopian the expressive, structural and symbolic functions of passages in Lutosławski's works, revising ideas of authenticity in Lutosławski’s music while introducing Foucault's little-known idea to a wider audience of music scholars, given the concept's potential to contribute to critical explorations of a diversity of musical texts and phenomena.

The spine of this essay, which develops these arguments over four ensuing sections, is formed by analytical observations concerning Les espaces du sommeil (1972-5), Lutosławski’s setting for baritone and orchestra of Robert Desnos's surrealist dreamscape 'The Spaces of Sleep' (1930). First, the essay presents a necessarily detailed overview of Foucault's notion of heterotopia and its subsequent adaptation by scholars, including a small number of musicologists; Lutosławski, of necessity, retreats into the background here, but only in order that notions central to the essay's later arguments about his music can be outlined with adequate clarity. The second and third sections examine moments in Les espaces du sommeil to explore the tension between the darker and brighter sides of Lutosławski's modernism; these sections also touch on broader topics in modernist aesthetics, including nostalgia, loss and hope. In the

${ }^{14}$ Fredric Jameson, Postmodernism, or, The Cultural Logic of Late Capitalism (London: Verso, 1991), 15. 
fourth section, the validity of the essay's claims about Lutosławski's heterotopias is assessed in the light of a number of relevant socio-historical and biographical contexts.

\section{Heterotopias}

An $f p$ thump from the timpani and strings cracks open a musical chasm two bars before rehearsal figure 92 of Lutosławski's Les espaces du sommeil; strings glissando and crescendo, charting the chasm's depths. 'In the night...' sings the baritone soloist, stepping into the breach as further thumps burst into showers of sparkling woodwind - '...there are the stars and the dark movement of the sea, of rivers, forests, cities, weeds'. Each noun is highlighted by melodic expansion, as the voice's rising tritone, $E b$ ('Dans la...') to $A($ '...nuit'), zigzags back to $E b$ and then up again to $C$, to $C \#$, and to $D$, heaving like a fugitive's breathing in a nightmare. The timpani and strings intensify their thump-and-slide gesture in parallel to the voice's panting and, as those sonorities also slip away from the $E b$ to which they were initially moored, the voice and ensemble's musical breathing becomes the bronchial heaving '...of the lungs of millions of millions of beings.' Plunging an octave and a half into the depths of the registral chasm with a fatalistic glissando, the voice then yields its central role to the orchestra, like a body falling into a volcanic fissure. Gobbets of musical magma spring up and collide, their trajectories laced with trumpet reminiscences of the voice's fall. The climactic eruption at Fig. 96 then razes even this lumbering trace of subjectivity, its maelstrom streaked with metallic brass. 
'In the night...' reiterates the baritone, miraculously returned to his perch on middle $\mathrm{C}$ and singing at the foot of an eerie yet scintillating seventeen-note string texture at Fig. 97 (see Example 1). Falling and rising melodic fragments, played on the glockenspiel and harp, highlight sections of this sonority - the strings sustain a symmetrical chord of interlocking major seconds and minor thirds - their antecedent and consequent phasing oddly prosaic in this strange new space. The baritone then explains that, in the night, 'there are the marvels of the world'. One marvel is the melody he proceeds to unfurl, its exoticism defined in part by its difference from the preceding prosaic fragments, but also by its languorous summoning of earlier modernisms (Debussy, Ravel, Szymanowski). The accompanimental sheen slowly darkens, however, and a penumbra of strings weighs down the melody, even as the line fashions a sense of centricity around the pitch-class E. For this night, the baritone explains, has no guardian angels, but at least there is sleep and there is 'you': here is a place to rest with the other being he has serenaded throughout Les espaces. Out of this moment of respite springs the voice's final, refortified statement, sung on the E above middle C. 'You' are also there 'in the day', he exults. The confidence of this line, powerfully sung in heroic isolation and harmonically centred by the preceding melodic preparation, reinforces his assertion; the orchestra then takes hold of the pitch, amplifies, distorts and explodes it. The music's assertion of hope scatters like a dream lost to consciousness.

\section{Example 1: Climax and aftermath of Les espaces du sommeil (Fig. $95^{+9}$ to} Fig. 97) 
Thus rupture leads to rapture leads to rupture once again at the end of Les espaces du sommeil, which climaxes, in Charles Bodman Rae's words, with 'the most magnificent and the most awesome ${ }^{, 15}$ in the series of crises from Lutosławski's pieces of the late 1960s and 70s - moments when a composition's discourse is rent open, releasing sounds that feel beautifully other. Unsurprisingly, these singularly dramatic moments have prompted notable criticism, several examples of which, including those in Zbigniew Skowron's important collection Lutosławski Studies, have rallied around the notion that these aftermaths yield transcendent consolations. For Rae, such moments demonstrate Lutosławski's aesthetic preoccupation with contrast, and in this case the contrast between the Sublime and the Beautiful (the dark, massive and painful Sublime yields to the Beautiful's lighter, more delicately pleasurable aftermath): ${ }^{16}$ for John Casken, such contrasts open 'new windows onto imaginary worlds' where one may experience 'a mysterious evocation of the Unknown, a dreamlike vision... or a moment of intense introspection,; ${ }^{17}$ for Maja Trochimczyk, Lutosławski's troping of the topics of mourning and death at his climaxes yields,

${ }^{15}$ Charles Bodman Rae, 'Lutosławski's Sound-World: A World of Contrasts', in Skowron, ed., Lutosławski Studies, 20.

${ }^{16}$ Ibid., 17-20.

${ }^{17}$ John Casken, 'The Visionary and the Dramatic in the Music of Lutosławski', in Skowron, ed., Lutosławski Studies (Oxford, 2001), 53. 
occasionally, to the hope of a coda in paradiso. ${ }^{18}$ As part of my own research into the relationship between Lutosławski's life, socio-historical contexts and music, I have begun interpreting his endings - and, in particular, their regular inclusion of passages of beautiful, mysterious, dreamlike, introspective and paradisial otherness that form a marked contrast to the turbulent, tragic and violent music that tends to encapsulate them - through ideas developed in Foucault's 1967 lecture 'Different Spaces', in which the philosopher outlines his intriguing notion of the heterotopia.

Foucault first deploys the term heterotopia in his preface to Les mots et les choses (1966; translated into English as The Order of Things, 1970). A delightful classification of animals imagined by Borges in a fictitious Chinese encyclopaedia (e.g., belonging to the Emperor, embalmed, tame, fabulous, that from a long way off look like flies) highlights, for Foucault, 'the stark impossibility of thinking that' within his own tradition of thought. ${ }^{19}$ As Peter Johnson explains in a useful overview of the history of the concept of heterotopia, this initiates the contrast Foucault then fashions between utopias, which, "however fantastic, present an ordered, coherent whole', and heterotopias, which shatter 'the usual

\footnotetext{
${ }^{18}$ Maja Trochimczyk, "'Dans la Nuit”: The Themes of Death and Night in Lutosławski's Oeuvre', in Skowron, ed., Lutosławski Studies, pp. 96-124; see esp. 118-119, including n. 28, which notes that Tadeusz Kaczyński was first to dub these gestures 'in paradiso'.

${ }^{19}$ Michel Foucault, The Order of Things (Andover, Hants.: Tavistock, 1970), xv. Original emphasis.
} 
ways in which words and things are drawn together'. ${ }^{20}$ In The Order of Things, this stimulates Foucault's examination of established forms of order in a particular culture and of how their basic codes govern perceptions and practices. Foucault then developed the idea of 'different spaces' as social sites rather than discursive spaces, first in a radio talk and then in a 1967 lecture to Paris's Architectural Studies Circle bearing the title 'Des espaces autre'. The focus of these texts is on sites that both reflect and contest their surroundings, thereby enclosing some form of deviation.

Although excerpts from the lecture subsequently appeared here and there, Foucault only agreed to its publication in 1984, shortly before his death, when it appeared under the title 'Des espaces autres' in the French journal Architecture, Mouvement, Continuité. ${ }^{21}$ An English translation under the title 'Of other spaces'

${ }^{20}$ Peter Johnson, 'History of the Concept of Heterotopia' (2012), 1. See http://www.heterotopiastudies.com/history-of-concept/ (last accessed 23 January 2014). Johnson's Heterotopia Studies blog and website is an accessible yet authoritative critical introduction to, and interrogation of, Foucault's concept. It is presently unparalleled in print media. Useful but more general overviews of Foucault's life and thought include Gary Gutting, Foucault: A Very Short Introduction (Oxford: Oxford University Press, 2005) and Paul Rabinow, ed., The Foucault Reader: An Introduction to Foucault's Thought (London: Penguin, 1984).

${ }^{21}$ Michel Foucault, 'Des espaces autre', Architecture, Mouvement, Continuitè (5) 1984: 46-49. 
was then published two years later in the journal Diacritics. ${ }^{22} \mathrm{~A}$ subsequent translation by Robert Hurley, retitled 'Different Spaces', ${ }^{23}$ forms the foundation of the survey below of the lecture's contents and, in turn, this section's engagement with Johnson's authoritative critique of scholarly adaptations of the concept of heterotopia, and of the ways in which Foucault's 'open-ended and ambiguous' accounts of heterotopia have 'probably provoked more discussion and controversy than any other of his minor texts' ${ }^{24}$

In 'Different Spaces', Foucault defines 'different emplacements' (note that the specific term he uses is emplacement, not space, connoting locations that are both places and spaces) 'that have the curious property of being connected to all the other emplacements, but in such a way that they suspend, neutralize, or reverse a set of relations that are designated, reflected, or represented by them'. ${ }^{25}$ The different emplacements on which he focuses are of two types, 'linked with all the [other emplacements], and yet at variance somehow with all the other[s]' (178): utopias and heterotopias. The first, utopias, 'are

${ }^{22}$ Michel Foucault, trans. Jay Miskowiec, 'Of other spaces', Diacritics 16 (1986): 22-27.

${ }^{23}$ Michel Foucault, 'Different Spaces', in J. D. Faubion, ed., Aesthetics, Method, and Epistemology: Essential Works of Foucault Volume 2 (London: Penguin, 1998), 175-185.

${ }^{24}$ Peter Johnson, 'Interpretations of Heterotopia' (2012), 4. See http://www.heterotopiastudies.com/wp-content/uploads/2012/05/3.1Interpretations-pdf.pdf (last accessed 23 January 2014).

${ }^{25}$ Foucault, 'Different Spaces', 178. Subsequent page references in text. 
emplacements having no real place... [that exist in] direct or inverse analogy with the real space of society'; they are, as such, society perfected or reversed, and thus 'fundamentally and essentially unreal' (178). (Why Foucault does not consider dystopias at this juncture is unclear, although fictive representations of dystopia, like utopia, also tend to reverse and, in a sense, 'perfect' the society on which they reflexively comment, as in 1984 or Brave New World.) Crucially, utopias are not real: they can only be imagined, not experienced.

The second type of emplacement, heterotopias, are 'designed into the very institutions of society' and form sites in which everything within a culture can be, 'at the same time, represented, contested, and reversed' (178) - a flourishing of difference in the midst of convention. Foucault then suggests that heterotopias must be fundamental to humanity's psychic needs as they have been constituted in every society throughout human history, with changing functions but consistent principles (179) - a bold claim that may lend impetus to the search not only for social sites with heterotopian functions, but also for cultural representations of this allegedly innate human desire to create these emplacements. It is therefore reasonable to enquire whether heterotopias might sometimes be represented within musical texts (while also asking how these differ from the non-heterotopian 'norms' also represented in the text) or, in other circumstances, fashioned socially by aspects of music's performance, creation or consumption (activities which might subvert texts designed to meet quite different imperatives; most music is not heterotopian, but any music, in theory, could become part of one's 
performance of a heterotopia).${ }^{26}$ In particularly compelling examples - intense examples, as Foucault called them - it is even conceivable that such emplacements will be shaped by music that both performs and represents heterotopia as part of a broader symbolic agenda. The later sections of this essay will return to these definitions in order to argue that passages in Lutosławski's music can indeed be heard as heterotopian.

Foucault outlines six principles of heterotopia. The first - that they are created in all societies throughout human history - indicates two main varieties of heterotopia: 'crisis heterotopias' and 'heterotopias of deviation' (179). Crisis heterotopias are "places reserved for individuals who are in a state of crisis with respect to society and the human milieu in which they live'; they include sites for menstruation and birth, rituals of adolescence and old age, and even the honeymoon trip - or, more precisely, the location of a virgin's deflowering (on a train, in a seaside hotel, etc.). He suggests that spaces of crisis are gradually disappearing, however, and being replaced by heterotopias of deviation: 'those in which individuals are put whose behaviour is deviant with respect to the mean or the required norm', examples of which, such as prisons and psychiatric hospitals, touch on familiar Foucault concerns (180). Foucault's second principle states that any society can make a new heterotopia that will 'operate in a very different way' from other heterotopias and have a 'precise and specific' function 'within the

${ }^{26}$ For a discussion of music designed to serve brute capitalist imperatives being subverted in the formation of heterotopian spaces of resistance, see the introduction to Marie Thompson and lan Biddle, eds, Sound, Music, Affect: Theorizing Sonic Experience (London: Bloomsbury, 2013). 
society' (180). That any heterotopia can be heterotopian in its own manner while fulfilling unique cultural work is perhaps the most generous of Foucault's six principles, opening the door to wide-ranging applications of his conception while, simultaneously, suggesting important criteria for adjudicating the merits of any such reading of a site or a text.

The third principle of heterotopia is their 'ability to juxtapose in a single space several emplacements that are incompatible in themselves' (181). Gardens are one of Foucault's key examples of heterotopia here, 'deeply symbolic' in nature and filled 'with meanings that were superimposed' (181). The archetypal ancient Persian garden was 'a sacred space that is said to have joined together within its rectangle four parts representing the four parts of the world, with a space even more sacred than the others which was like the umbilicus, the navel of the world at its centre (this was the location of the basin and the fountain)' - a 'figurative microcosm' yielding a 'blissful and universalizing heterotopia' (181-82). Fourth, heterotopias are connected with 'temporal discontinuities' and formed through 'a kind of absolute break with... traditional time' (182). Foucault lists fairs, 'those marvellous empty emplacements on the outskirts of cities that fill up once or twice a year with booths, stalls, [and] unusual objects' (182) as examples fulfilling this principle.

Fifth, gaining access to a heterotopia is not so simple: 'a certain number of gestures have to be performed' (183). The seedy motel room as the site of an illicit affair is Foucault's piquant example: one must travel to it with a car, a lover and some cash, book in and gain the key before embarking on 'unlawful sexuality... absolutely sheltered and absolutely hidden' (183-84). Sixth, lastly and 
crucially, heterotopias 'have a function in relation to the remaining space' (184). This can be one of two things: a revelation concerning the illusory nature of aspects of the conventional emplacements making up the society that plays host to a heterotopia, or 'the heterotopia not of illusion but of consolation': 'a different space... as perfect, as meticulous, as well-arranged as ours is disorganized, badly arranged, and muddled' (184).

This leads to Foucault's final image - sailing vessels as 'the heterotopia par excellence' (185). A ship is 'a floating space, a placeless place, that lives by its own devices, that is self-enclosed and, at the same time, delivered over to the boundless expanse of the ocean, and that goes from port to port' as a 'reservoir of imagination' (185). Perhaps not entirely disconnectedly, the composer of Les espaces was a keen sailor and an admirer of fictional maritime adventures, not least those by Joseph Conrad, which include a few heterotopias of their own. In one snapshot included in the plates within Rae's The Music of Lutosławski, he is shown sailing on Lake Michigan with the Chicago skyline in the background, around the time of the premiere of his Symphony No. 3 in the early 1980s - a composer tacking away from icons of modernity and into a wide-open space.

At one point in his lecture, Foucault envisages a collective of scholars engaged in 'heterotopology', i.e., in 'studying, analyzing, describing, "reading," as people are fond of saying now, these different spaces, these other places' $-a$ vision of scholarship that could, in turn, be 'read' to suggest that such thinkers, like the spaces they examine, also form 'a kind of contestation, both mythical and real, of the space in which we live' (179) - or, at least, a contestation of the disciplinary discourses to which they customarily contribute. By the second 
decade of the twenty-first century, 'Heteropology' has indeed expanded to include notable contributions from (to name but a few) architects, sociologists, cultural geographers, literary scholars and post-colonial theorists, not to mention scholars of engineering, management theory and childhood studies. ${ }^{27}$ Some even seek 'to transform the way we live', or at least the way we work and think, through critical texts that 'dream of alternative futures' ${ }^{28}$ Mirroring wider trends in the adaptation of critical-theoretical terminology, many scholars have nevertheless used Foucault's term 'heterotopia' impressionistically, with little detailed reference to the specifics of his lecture; others, also problematically, have sought to tie heterotopia to a single cultural-historical moment, period, or aesthetic tradition. ${ }^{29}$ The small body of musicological work to have engaged thus far with the concept of heterotopia is not immune, in places, to criticism along these lines. On the other hand, whether or not some uses of the term are ultimately appropriate, much of the research inspired by Foucault's concept (musical or otherwise) offers unexpected angles on important topics. In a sense, the idea of heterotopia - like other fertile critical-theoretical concepts - has itself become a heterotopia: a reservoir for the imagination and a space in which

${ }^{27}$ For an overview of existing work see Johnson, 'Interpretations'.

${ }^{28}$ See the cover blurb for Caroline Baillie, Jens Kabo and John Reader, Heterotopia: Alternative Pathways to Social Justice (Winchester: Zero Books, 2012).

${ }^{29}$ See Peter Johnson, 'A Question of Modernity?' (2012) at http://www.heterotopiastudies.com/wp-content/uploads/2012/05/3.2-A-Questionof-Modernity-pdf.pdf (last accessed 24 January 2014). 
scholars feel empowered to represent, reverse or contradict conventional wisdom in their disciplines.

Foucault's lecture has served as an impetus for music scholars eager to insist on the politically significant otherness of certain spaces, texts and identities, the value, richness and importance of which their work seeks to demonstrate. An early example of a musicological engagement with the notion of heterotopia can be found in Philip Bohlman's scrupulously contextualized 2002 essay 'Jüdische Lebenswelten zwischen Utopie und Heterotopie, jüdische Musik zwischen Schtetl und Ghetto'. ${ }^{30}$ One of the merits of Bohlman's text is the manner in which it respects a key aspect of Foucault's approach to heterotopias: Bohlman's focus on music's function between schtetls and ghettos parallels Foucault's argument that, rather than marking sites of radical otherness, heterotopias must be understood in relation to other sites, because heteropology must seek to 'establish the possible connections between disparate terms which remain disparate'. ${ }^{31}$ Music scholars have also asserted heterotopias in the

${ }^{30}$ Philip Bohlman, ‘Jüdische Lebenswelten zwischen Utopie und Heterotopie, jüdische Musik zwischen Schtetl und Ghetto', Lied und populäre Kultur 47 (2002), 29-57.

${ }^{31}$ Michel Foucault, The Birth of Biopolitics: Lectures at the Collège de France 1978-1979 (New York: Palgrave Macmillan, 2008), 42. Cited in Peter Johnson, 'Heterotopia: Foucault and Space (6)', http://www.heterotopiastudies.com/blog/page/9 (2014), last accessed 24 January 2014 
musical spaces that serve in lesbians' coming out geographies; ${ }^{32}$ in East Asian screen representations of Taiwanese 'acoustic guitar heroines' embodying an 'ethos of individualism and self-expression' in a wider relationship to prevailing 'discourses of nation and gender'; ${ }^{33}$ as part of a theorizing of categories of musical community; ${ }^{34}$ and in twelve-note music when read, in toto, as 'a kind of virtual heterotopia, an ephemeral environment of disquieting reinvention and always morphing cultural boundaries, ${ }^{35}$ Not all of this work clarifies the extent to which it is grounded in a theoretically engaged interpretation of Foucault's six principles and his wider framing of the concept. At the very least, however, the essays demonstrate that other musicologists have sensed the potential value of seeking out heterotopias.

${ }^{32}$ Lisa Hardie, 'Staying in, tuning in, and coming out: Music as imagined space in lesbians' coming out geographies', MA thesis (University of Waikato, 2012). Available at http://researchcommons.waikato.ac.nz/bitstream/handle/10289/6639/thesis.pdf?s equence=3 (last accessed 24 January 2014).

${ }^{33}$ Eva Tsai and Hyunjoon Shin, 'Strumming a Place of One’s Own: gender, Independence and the East Asian Pop-Rock Screen', Popular Music 32/1 (2013), 7-22.

${ }^{34}$ Kay Kaufman Shelemay, 'Musical Communities: Rethinking the Collective in Music', Journal of the American Musicological Society 64/2 (Summer 2011), 349390.

${ }^{35}$ Martin Brody, 'Review: Twelve-Tone Music in America by Joseph N. Straus', Journal of the American Musicological Society 65/1 (Spring 2012), 297. 
The possibility that musical texts can structure virtual heterotopias - i.e., sensuously and symbolically tangible representations of heterotopian ideals that function in relation to an encompassing realm of aesthetic and ideological conventions - has been provocatively explored by Gary C. Thomas in a fascinating essay on screen music. Thomas asks whether encountering latemodern representations of heterotopias 'put us at risk, and bring us into the open-ended possibilities of experimentation, improvisation, and play,. ${ }^{36}$ Hence his discussion of the sequence from Bob Rafelson's film Five Easy Pieces (1970) in which Bobby (played by Jack Nicholson) performs Chopin on an out-of-tune piano being transported on the back of a flatbed truck. In this fabulous scene, Bobby is stuck in traffic. Annoyed, he climbs out of his truck and protests against the general inanity of freeway traffic jams ('lining up like a goddamn bunch of ants during the most beautiful part of the day!'), before rebelling further by clambering up onto another vehicle to examine its contents. The removal truck is transporting, amongst other things, the aforementioned piano. Marvellously (because the action is so unexpected and incongruous), Bobby lifts the lid, plays a couple of deftly executed scales, and then sits down to begin a virtuoso performance of Chopin's F minor Fantasy. As other drivers honk their horns in a mounting cacophony of objections heard simultaneously with the Fantasy (their 'meanings... superimposed', as Foucault writes of the quarters of a Persian

${ }^{36}$ Thomas, Gary C., 'Men at the Keyboard: Liminal Spaces and the Heterotopian Function of Music', in Daniel Goldmark, Lawrence Kramer and Richard Leppert, eds, Beyond the Soundtrack: Representing Music in Cinema (Berkeley, CA: University of California Press, 2007), 280. 
garden), the music begins to shift affective gears and the truck pulls away taking a hitherto unnoticed exit ramp. A musical heterotopia (and a Polish one to boot) is thereby carried away from the honking clamour of twentieth-century modernity.

This musical interlude, Thomas argues, 'stages the only moment of integration for Bobby' in the film, in which his musicianship fuses briefly to a purpose of achieving 'sheer personal joy'. ${ }^{37}$ That Thomas hears specifically heterotopian dimensions in Chopin's F minor Fantasy to match the scene's representation of Bobby's subjectivity - moments that 'ebb and flow, move often non-teleologically in and out of affective spaces', and thus feel 'open-ended and unbound $^{\prime 38}$ - might encourage similar considerations of concert music, such as whether Lutosławski's climaxes and, particularly, markedly different aftermaths share some of these traits, offering liberating visions of less constrained subjectivities and worlds. The wider context of Thomas's analysis (his critique of musical passages in films 'staging moments of liminality, where the psychic and social wounds of modernity - contradictions and alienations of the twin-headed oedipal-capital machine - are rent open and, as it were, made public) ${ }^{39}$ may lend momentum to the desire to interpret music's cultural work in a similar fashion.

Before undertaking heteropological endeavours, however, one would be wise to observe Johnson's note of critical caution. It is possible that some of the musicology cited above would fall victim to Johnson's admonishing of acts of

${ }^{37}$ Ibid., 287.

${ }^{38}$ Ibid., 288.

${ }^{39}$ Ibid., 281. 
cultural criticism that, rather than emphasizing heterotopias via 'the relational "difference" from, or transformation of, the ordinary', retain 'the connotations of a radical alterity or spaces that are fundamentally other'. ${ }^{40}$ Taking their cue, he suggests, from little more than the middle word in the 'Of other spaces' title of the first translation of Foucault's lecture, 'many interpreters of heterotopia... introduce the upper case "Other" within their discussion'. ${ }^{41}$ Examples he examines of this shift include David Hetherington's definition, in The Badlands of Modernity: Heterotopia and Social Ordering (1997), of spaces shaping 'an alternative ordering that marks them out as Other'; ${ }^{2}$ Johnson also notes critics who, following Hetherington's lead, have made claims for heterotopias as spaces of Otherness. ${ }^{43}$ Foucault's thoughts on heterotopia, Johnson stresses, emphasize relational difference, not radical forms of alterity. Yet there is no a priori reason to claim that musical heterotopias could not form part of performances of radical difference in a particular cultural community. Musical emplacements exploring their relationship to, as much as their differences from, other emplacements may nonetheless prove to be more productive sites for the discovery of musical heterotopias.

One test of whether or not a putative instance of musical heterotopia is

40 Johnson, 'History', 3.

41 Ibid., 3.

${ }^{42}$ David Hetherington, The Badlands of Modernity: Heterotopia and Social Ordering (London: Routledge, 1997), viii.

${ }^{43}$ David Harvey, Spaces of Hope (Edinburgh: Edinburgh University Press 2000), 185. 
worthy of the designation is whether or not a significant proportion of Foucault's six principles can be demonstrated to cluster within it - and without too much critical strong-arming. As Johnson suggests, '[h]eterotopian sites emerge when and where certain attributes', represented by Foucault's six principles, 'join forces, forming a cluster or network'. ${ }^{44}$ Further testing could relate to a tripartite consideration of whether some of the example's musical, cultural and socioeconomic functions are also, to some extent, demonstrably heterotopian, in accordance with Foucault's broader discussions. The extent to which Les espaces du sommeil and other examples of Lutosławski's music fulfil these requirements will be considered in the final section of this essay, in light of the ensuing analyses. However, if the idea of heterotopias in music has critical potential, one should easily be able to develop similar arguments regarding alternative repertoires and musical activities. ${ }^{45}$

Charting music's heterotopias more widely may therefore prove to be a surprisingly productive endeavour. For the purposes of the present essay, though, it is necessary now to turn fully to Lutosławski, in order to consider, first, whether sections of his music form emplacements of the more conventionally recognizable traits of modernist musical authenticity and, thus, musical situations within which heterotopias might emerge as sites of contradiction, reversal or
44 Johnson, 'History', 3.
${ }^{45}$ The musical, political and personal identities formed in the texts and spaces of rave spring to mind. See Maria Pini, 'Women and the Early British Rave Scene' in Angela McRobbie, ed., Back to Reality? Social Experience and Cultural Studies (Manchester: Manchester University Press, 1997), 152-169. 
transformation - as the spaces of dream.

\section{Lutosławski and the music of 'la nuit'}

Throughout Lutosławski's music after 1960 one hears traces of that most human of sufferings identified by the composer - loneliness - and not least in the ways that Lutosławski allows his moments of consolation to founder, as in the detonation of hope and companionship at the end of Les espaces du sommeil. This aspect of the composer's aesthetic will come as no surprise to those Lutosławski specialists quoted earlier, whose views this essay initially oversimplified for rhetorical purposes. Rae, for instance, more precisely defines the 'most sublime things' in Lutosławski's output, such as Les espaces's climactic maelstrom, by quoting Johann Georg Sulzer's late eighteenth-century encyclopaedia of artistic theory. Sulzer argues that evocations of the sublime 'should be resorted to only when the psyche is to be attacked with hammerblows' and 'whenever the aim is to intensify the powers of the soul or violently to curb them' ${ }^{46}$ Note that subjectivity may take a hammering, or be violently curbed, at such moments, and then consider Casken's description of the two flutes in the coda of 1968's Livre pour orchestre as 'singing voice[s] emerging from the culminating noise'. ${ }^{47}$ These ghosts of the surging string cantilena in Livre's Finale

${ }^{46}$ Johann Georg Sulzer, Allgemeine Theorie der schönen Künste, in einzelnen, nach alphabetischer Ordnung der Kunstwörter aufeinanderfolgenden Artikeln abgehandelt Leipzig, 1792-4), iii., 512-13. Trans. In Rae, 'Lutosławski’s SoundWorld', 19.

${ }^{47}$ Casken, 'The Visionary', 40. 
come across as fugitive subjectivities, escaping from a consolatory climax that may not, after all, have afforded an unambiguously positive realization. Indeed, as Casken argues via his essay's engagement with George Steiner's Real Presences, such musical visions may ultimately lead us 'towards our apprehension and sufferance of death' ${ }^{48}$ Trochimczyk, in turn, complicates the in paradiso ending of works like Livre by noting 'the disappearance of [their] ascending sonorities' - and thus of their symbol of hope for a better world beyond the present domain of suffering - which vanish 'into thin air'. ${ }^{4}$ Consolation and hope in Lutosławski: now you hear them, now you don't. What does this signify, and what is happening, crucially, in the musical detail of such moments?

Lutosławski's more pessimistic passages can be read as conventional emplacements of modernism's 'stunned and dispirited' remembrance, in Eagleton's words, of more stable systems of meaning now past:

The typical modernist work of art is still haunted by the memory of an orderly universe, and so is nostalgic enough to feel the eclipse of meaning as an anguish, a scandal, an intolerable deprivation. That is why such works so often turn around a central absence, some cryptic gap or silence which marks the spot through which sense-making has leaked away. ... In

${ }^{48}$ George Steiner, Real Presences (London: Faber \& Faber, 1989), 63; quoted in Casken, 'The Visionary', 53.

${ }^{49}$ Trochimczyk, 'The Themes of Night and Death', 119. 
the tension between the persisting need for meaning and the gnawing sense of its elusiveness, modernism can be genuinely tragic. ${ }^{50}$

Joseph K's nameless crime, the never arriving Godot, the heart of darkness, the missing lover in Erwartung: can one also think of adding moments in Lutosławski's scores to this selection of modernist vanishing points? To do so, alongside identifying its passages of acceptable unacceptability, one has to investigate ways in which Lutosławski's music sounds 'easy' yet demonstrates symbolic multivalency.

In a recent study of nostalgia, Svetlana Boym argues that ' $[\mathrm{m}]$ odern nostalgia is a mourning for the impossibility of mythical return, for the loss of an enchanted world with clear borders and values':

[l]t could be a secular expression of a spiritual longing, a nostalgia for an absolute, a home that is both physical and spiritual, the edenic unity of time and space before entry into history. The nostalgic is looking for a spiritual addressee. Encountering silence, he looks for memorable signs, desperately misreading them. ${ }^{51}$

Boym adds a melancholy undertone to her portrayal of reminiscence as utopian fantasy - fantasies that can usefully be filtered, in the context of the present discussion, through her interpretation of Polish conceptions of nostalgia. Most national literary traditions, Boym notes, developed a special word for homesickness that was 'radically untranslatable', but she unpacks the meanings

${ }^{50}$ Terry Eagleton, The Meaning of Life (Oxford: Oxford University Press, 2007), 100.

${ }^{51}$ Svetlana Boym, The Future of Nostalgia (New York: Basic Books, 2001), 8. 
of the Polish term tesknota - a word one might usefully deploy alongside żal to plumb the depths of Polish melancholy. Sharing the same root as the Russian toska, but usually considered its opposite, 'tesknota gives a... sense of confining and overwhelming yearning with a touch of moody artistry'; she also quotes Eva Hoffman's description of tesknota as a 'phantom pregnancy, a "welling up of absence" and all that has been lost. 52

Leaving aside for now the extent to which Boym's descriptions evoke aspects of Les espaces (the last two sentences of the above quotation, for instance, may remind one of the persona's desperate search for 'toi', his spiritual addressee), which absences might be welling up in Lutosławski's music? Like every Pole of his generation, Lutosławski was horribly well-acquainted with losses personal, national and cultural. He was not only scarred by events such his father Józef's execution when Witold was just 5 years old (one of the composer's earliest memories was of visiting his father to say goodbye to him in prison, just hours before Józef's death by firing squad). The opening essay in Skowron's recent Lutosławski on Music collection, Lutosławski's 1993 acceptance speech on receiving the Kyoto Prize for Creative Arts and Moral Sciences, demonstrates the extent to which the composer continued to recall less obviously traumatic losses until the end of his life - perhaps as a publicly admissible synecdoche for a nexus of even more painful losses. Lutosławski writes of the influence of growing up surrounded by nature in the landscaped

\footnotetext{
52 Ibid., 12; see also Eva Hoffmann, Lost in Translation: A Life in a New Language (New York: Penguin, 1989), 115, cited in Boym.
} 
gardens of his family estate in Drozdowo - a space that remained, he said in Kyoto, 'still in my memory' in what proved to be the last year of his life:

The place was beautiful, with a splendid view from the garden on the river Narew. It was not without influence on my character that I spent my early years in contact with nature. Beautiful forests, fields, rivers, meadows, and gardens are still in my memory, although the estate has not belonged to my family for many years. ... Our estate was ruined by the war and never returned to its former state..$^{53}$

Bearing in mind that, for Foucault, formal gardens are a key example of heterotopia, one might wonder at the parallel impacts on the young Lutosławski's psychology when he returned to Drozdowo from Moscow, having just lost his father, only to find his beloved gardens - spaces of freedom, play, discovery and imagination - ruined by war. Thereafter, Lutosławski told Zofia Owińska in an interview shortly before his death, he became a 'rather unusual child', immersed in music, but surrounded by a 'devastated' estate where '[e]verything was damaged, on the verge of disintegration, all of which, combined with the family tragedy... made my childhood not very cheerful at all. ${ }^{54}$ These suggestive biographical facts are nonetheless symptoms of broader historical forces that

\footnotetext{
${ }^{53}$ Witold Lutosławski, 'Introduction: Witold Lutosławski’s Life and Music' (1993), edited and trans. in Zbigniew Skowron, Lutosawski on Music (Lanham, MA: Scarecrow Press, 2007), xiii-ix.

54 Zofia Owińska, trans. John Comber, Up Close with Lutosławski (Kindle Edition: Agata Igielska-Szalay, 2014), 'Conversation I: 25 April 1992. Part I'.
} 
marked, in turn, vast swathes of twentieth-century culture to which Lutosławski's music deserves to be connected.

Fusing Boym's ideas on nostalgia and critical approaches to musical modernism in a manner that provided a helpful model for the present essay's considerations, Jonathan Cross has offered a persuasive reading of the similarities, rather than differences, between Schoenberg and Stravinsky's early modernisms - a useful divide to bridge, in a Lutosławski context, given the composer's self-serving tendency to echo narratives of innovation bifurcating around those two composers. Cross directs attention to the poignancy with which the opening of Schoenberg's Op. 11 piano pieces 'highlights the gap between the atonal present and the tonal past... as if we glimpse the past through Schoenberg's glass, darkly'. ${ }^{55}$ Going on to discuss the close of the first movement of Stravinsky's Symphony in C (an ending that is anything but exactly 'in' C), Cross then links the just-out-of-reachedness of tonality in these works not just as a means of pitch organization, but as an entire meaning-making system - to a reading of modernist art that is characterized 'by such features as alienation, nostalgia, loss and mourning' ${ }^{56}$ This kind of modernist music dwells, for Cross, on the loss of what Adorno called the constitutive subject and also 'on

${ }^{55}$ Jonathan Cross, 'Paradise Lost: Neoclassicism and the Melancholia of Modernism', in Dejan Despić and Melita Melin, eds, Rethinking Musical Modernism, Academic Conferences of the Serbian Academy of Sciences and Fine Arts, Vol. CXXII, Department of Fine Arts and Music, Book 6 (Belgrade, 2008), 58.

${ }^{56} \mathrm{Ibid}$., 60. Subsequent references in this paragraph from same page. 
the impossibility of its retrieval; in so doing he keeps alive its image as a critique of the present' - a musical representation of a modernist Weltanschauung. In moments when tonality is so near and yet so far, Cross writes, one may experience, through musical representation, 'the alienated late-modern subject, freighted with a melancholy nostalgia for a past that is lost, for a completeness that can never be regained'. Cross subsequently claims that 'this theme of the alienated subject is a thread running through the work of many late-modern figures, from Mahler to Birtwistle'.

And also, one could argue, to Lutosławski. One can easily find moments of tonality through a glass darkly in Lutosławski's music: the microtonally-veiled triads at the start of Livre; the nostalgia for diatonicism in the bucolic second phase of the Cello Concerto, in turn a series of reflections on its opening section's key idea (a quasi cadential I-II-V motif); the E major scale based eightnote climax of Chain 3 (1986); the 'E minor' opening of Symphony No. 4, dialectically contrasted to the second subject group's 'Bb major'. One must also, though, consider longer-range musical processes alongside these isolated features. In Lutosławski's music, one often finds examples of relative consonance poisoned by dissonance - such as the penumbra of darkness that forms beneath the baritone's enraptured melody at the end of Les espaces. As Steven Stucky has demonstrated, the diatonic/chromatic expressive contrast is a thumbprint of modernist compositional practice that interconnects large amounts of stylistically varied repertoire (including Lutosławski's works) over at least a 
hundred years. ${ }^{57}$ Analysing the textual meanings generated by the structural contexts within which such tropes are realized is thus a potentially productive critical concern.

After the introductory string and harp gestures sink into the spaces of sleep in the first phase of Les espaces, the overall structure of which is represented in Table 1, one hears evocations of the 'toi' being sought by the persona in three brief statements. This refrain alternates with longer verses evoking the horrors of 'la nuit'. That night is depicted, in part, through the intervalclass pairing $1+3$, and in febrile textures that centre around the pitch class $A$, so there is a sense of chromaticism yielding to diatonicism, and even minor yielding to major, when the first 'toi' sounds.

\section{Table 1: Structural overview of Les espaces du sommeil ${ }^{58}$}

The 'toi' refrain's paradigmatic statement consists of the composer's favoured diatonic tetrachord, pitch-class set 4-23 or [0257], which embodies the consonant i.c. pairing $2+5$ and, on its first appearance at Fig. 10, is rooted on C,

${ }^{57}$ Steven Stucky, 'Heart and brain, tradition and modernism: a key moment in Lutosławski's Fourth Symphony', paper given at the conference 'Muzyka Witolda Lutosławskiego u progu XXI wieku. Dookreślenia - oceny - perspektywy', Narodowego Instytutu Fryderyka Chopina, Warsaw (26-27 September 2013).

${ }^{58}$ Section timings from Christopher Purves's recording with the BBC Symphony Orchestra conducted by Edward Gardener, Lutosławski Vocal Works (CD, Chandos Records: CHAN 10688, 2011). 
as emphasized by the horn chord and baritone melody. In addition, the $\mathrm{C}$ major scale's third step, E, sounds in the middle of the texture, distinctively marked by the harp. E sounds both within and outside of the moment, as befits a pitch-class with its own structural destiny in the piece (i.e., its role at the end) and it recurs unchangingly on each refrains' glimpse of 'toi': a benchmark against which to measure their gradual descent into darkness. Over its three occurrences, the 'toi' key idea becomes chromatically more corrupted, distancing 'toi' from the persona and alienating him still further as each sonority and descending bass note slither closer to the music of 'la nuit' (see Ex. 2).

\section{Ex. 2: Gradual chromatic corruption of diatonic 'toi' refrains in Les espaces du sommeil}

What makes the acceptably unacceptable side of Lutosławski's modernism authentically melancholic, one could thus begin to argue, is the manner in which it is not merely his musical language that nostalgically reaches out to a never-to-be-regained past. His structures also continually enact a getting close to, and then loss of grip on, the enchanted kingdom of music before modernity. The symbolic story emerging - not just of consoling spaces lost, but also of the journey to, through and away from such losses - involves a 'genuinely tragic' modernism shaping musical tests of the moral imagination. Lutosławski's approach to both musical structure and pitch organization re-imagine and interrogate some of tonality's main plot archetypes, and it is vital to remember that, more often than not, his structures collapse syntactically (just as Harley 
noted) at precisely the point where, at least in common-practice tonal music after Beethoven, one might hope to hear the forging of a triumphant, tragic or transcendent synthesis. Instead, Lutosławski ruptures the rapture, as in the detonation at the climax of Les espaces. This is not a failing: it is a seat of his music's expressive and symbolic power.

A key difference between Schoenberg and Lutosławski, and perhaps more generally between earlier and later musical modernisms, may be that later composers, having lived through yet greater catastrophes, truly know there is no hope. Some later modernists, paradoxically, may nevertheless have reasons to offer an alternative perspective from those who eradicate hope and subjectivity entirely from their art. Cross quotes Adorno, in the Philosophy of New Music, interpreting the third part of Schoenberg's Pierrot Lunaire as "a "journey home" to a vitreous no-man's-land' in which 'the quasi-transcendental subject... recovers himself on an imaginary plane': like 'a castaway finding rescue', this offers 'an image of hope for the hopeless'. ${ }^{59}$ Early modernism, one might thus suggest, continues to hope for rescue from the alienation of the late-modern subject's desert island. The ingrained cynicism of later modernisms - Polish musical modernisms after Auschwitz, say - permits the subject to board the heterotopian rescue boat, then torpedoes it in an act of pitiless honesty. One encounters this honesty in Lutosławski when struggle leads not to victory or melodramatic tragedy but instead to rupture, violence, lament and the shattering of

${ }^{59}$ Cross, 'Paradise Lost', 59; quoting Theodor Adorno, Philosophy of New Music, trans. Robert Hullot-Kntor (Minneapolis: University of Minneapolis Press, 2006), 109. 
consciousness (as in the String Quartet of 1964); when a moment of victory reveals itself as pyrrhic (as in the Cello Concerto, whose ending recaptures the opening's bright atmosphere, but as if in the next world); and when, most disturbingly of all (and as in Les espaces), his music immerses the 'quasitranscendental subject' in a vision of escape into a beautifully other space - a heterotopia forged, in part, of reimaginings of tonality's wholeness and its functioning community of sounds - before, to recall Hoffman's definition of tesknota, aborting the phantom pregnancy with a gesture of steely brutality.

\section{Lutosławski's Heterotopias}

If brutally tragic gestures help to signify the acceptably unacceptable cornerstone of Lutosławski's modernism, what can be said of their heterotopian counterbalance? The persona in Les espaces is desperately seeking 'toi': another to whom he is drawn, and yet from whom he is separated, from the start, by the refrain's haze of diminishing consonance. The persona therefore dreams, alternately, of alienation and communion, the latter with this other persona, 'toi', who is perhaps just an aspect of his own fragmented subjectivity: anything to stem the horrors of 'la nuit'! Like other surrealists, Desnos is fiercely modernist in his thinly-veiled consideration of the psychological underpinnings of the human condition: the seductiveness of his dreamscape's 'Traum-melodie' ${ }^{60}$ entices recognition of what lies beneath us all - and the realization that the answer to

${ }^{60}$ The term is Hugo Friedrich's and cited in Benoît Aubigny, 'Poetic and Dramatic Schemes in Lutosławski's Vocal-Instrumental Works', in Skowron, ed., Lutosławski Studies, 59. 
that question may be nothing at all or, worse still, merely oneself. Yet his writing also expresses a contrary desire to find footholds for uncanny forms of beauty in the face of abjection and despair. Benoît Aubigny, for instance, notes the 'astonishing care' Desnos appears to have taken in the construction of his poem, the structure of which has nothing hallucinatory or conventionally shocking about it. ${ }^{61}$ Lutosławski's setting amplifies these complexities and tensions, and not merely at the surface level of the three refrains' glimpses of heterotopia sailing off into the distance.

The loss of 'toi' and its diatonic realm in the first phase of Les espaces does not lead to the uninterrupted bleakness of 'la nuit' - although it sets up a dialectical opposition that can only go awry in a modernist musical narrative. Part of the thrill of this deceptively 'middlebrow' plotting - deceptive because it is anything but straightforwardly thrilling and thus 'middlebrow' - lies in the manner in which it denarrates its own story in challenging ways. The episodes and refrains (refer back to Table 1), for instance, form the first in a series of hierarchically nested heterotopian spaces, each of which respond to and then cede to ruin. When the first phase's third and most corrupted glimpse of 'toi' fades, for instance, a junkyard of chromaticism ensues (Fig. 23). This is genuinely chaotic music, with no audible trace of micro-structural logic to alleviate the loss of centre suggested by Desnos's nightmarish Catch-22 ('Mais encore moi que me poursuis/ou sans cesse me dépasse'), which describes the persona's self-pursuing and overtaking itself in an endless spiral of missed

${ }^{61}$ Ibid., 58. 
connections. The persona's night terror yields, however, to the music's second phase and the luminosity of its central dreamscape (see Ex. 3).

\section{Ex. 3: Start of the Tranquillo, Les espaces du sommeil Fig. 24-29}

During the tranquillo, as the persona redefines 'toi' as the soul of a universal expanse that his dreaming must somehow traverse, Lutosławski takes the epitome of erased musical subjectivity - the 12-note row - and manipulates it to yield quasi-tonal islands of calm that revise the piece's earlier glimpses of 'toi', developing them to form the basis of the section's exquisite string harmonies and the baritone's searching melodies. During the ensuing section's push to catastrophe, the baritone's melodies will also be based on the row - until the climax, discussed above, at which point its identity is surrendered. Rethinking set-class 4-23 - the veil of 'toi' - proves central to this process. The tetrachord's inner and outer intervals become the limited interval-class identity of the section's row (it pairs i.c.s $2+5$, i.e., wholetones, perfect fourths and their inversions). In the tranquillo, this permits Lutosławski's persona to set sail in a fantastical space between 'nuit' and 'toi', modernism and pre-modernism, serial and neo-tonal musical thought, as the 'toi' and 'nuit' key ideas are refracted, like a symphonic development section through a glass, but not darkly - kaleidoscopically.

Initially, the strings present a looser ordering of tones - or rather, a version of the 12-note set that anticipates qualities of the row to follow while permitting an alternative symbolic signpost to be constructed. The section begins rooted on $\mathrm{C}$, a pitch class that has already been harmonized (but not tonicized) by the 
introduction and the 'toi' refrain's 4-23 p.c. set. Basses and violas sustain $C$ and $D$, the cellos enter on $F$ and the piano flourish adds the missing $G$. The next sustained pitch is an A, the 'nuit' reference pitch. This picks up on the iteration of the pitch-class in the flute and glockenspiel's chromatic embellishment - the first of the section's night music-like birdcalls, which enable regular turnover of the chromatic set and thus establish (with the strings' ebb and flow) a free floating, rather than teleological, sense of harmonic evolution across the tranquillo. The pitch-class's nuit associations are thereby subjugated as the baritone hails the sacrificed, yet apparently immortal, 'toi'. With the addition of E and B by Fig. 29, the strings sustain the seven notes of the $\mathrm{C}$ major scale: a diatonic cushion against which alternative harmonic forms impress themselves. By the end of the tranquillo, however, all twelve-notes of the chromatic scale will accrue. The tranquillo is thereby bookended with a version of the diatonic/chromatic opposition Stucky has noted, which in the context of Les espaces develops the refrains' chromatic poisoning as a larger-scale gesture shaping the entry and exit points of the piece's central heterotopia.

\section{$P^{0}$ proper (C D A G F A\#D\#C\#G\#F\#B E; see Table 2) then begins at} Fig. 36. $I^{9}$ follows at Fig. 48 , starting on $\mathrm{A}$, not $\mathrm{C}$, and, like subsequent row-forms $\mathrm{P}^{7}$ and $\mathrm{I}^{4}$ (the latter cut short by two pitch-classes to end on a $\mathrm{C}$ ), permits the sustained string and baritone harmonies to focus on the reference pitches. At Fig. 50, the 'll y a toi' refrain is revisited, but now centred on A, like a sonata form development drawing a second subject closer to the tonic - although the voice's climax in this section, at Fig. 68, peaks on the $\mathrm{E}$ above middle $\mathrm{C}$, foreshadowing the role of that pitch-class at the end of the piece. The tranquillo then ends with 
the strings' accrual of a densely chromatic sonority against which the baritone iterates repeated Es an octave lower, its centricity lost in the fug of dissonance as the pitch-classes of the final $\mathrm{I}^{4}$ row-form all sustain in a 12-note cluster as it progresses from $\mathrm{E}$ back to $\mathrm{C}$ - the pitch-class on which the dreamscape began, now subsumed by the darkness of 'la nuit'.

Table 2: Row forms in the Tranquillo

\begin{tabular}{|l|l|}
\hline Figs & Row form \\
\hline $36-47$ & $P^{0}:$ C D A G F A\#D\#C\#G\#F\#B E \\
\hline $48-60$ & $I^{9}:$ A G C D E B F\# G\# C\#E b B b F \\
\hline $61-72$ & $P^{7}:$ G A E D C F B b A b E b C\# F\#B \\
\hline $73-82$ & $I^{4}:$ E D G A D bE b A b B b F C (incomplete) \\
\hline
\end{tabular}

If this central passage is a heterotopia, it is more sustained than the initial 'toi' refrains, whose glimpses it expands; but it is also haunted, like the short refrains, by eddies and, eventually, an accrual of darker chromaticism. In turn, furthermore, this mid-level structural process of heterotopic termination is nested within the overarching structure of a larger-scale musical narrative, the third phase of which sets Desnos's depiction of the journey to the brink of subjectivity's annihilation. In the climactic passage at the peak of this third phase, described earlier in this essay, Lutosławski's baritone evokes Desnos's lungs of millions hollering themselves hoarse, like a choir of Edvard Munch screams - the point at which the baritone line abandons iterations of rows linking back to the tranquillo. Structurally, this forms a counterbalance to the central dreamscape, as 
if that vision of tranquillity required an equally intense vision of horror. It too, though, will be answered.

Lutosławski's brutally sensuous climax - the visceral nature of which is reminiscent of the shattering violence at the culmination of some of Birtwistle's contemporaneous pieces, e.g., The Triumph of Time (1972) - is also the music's syntactical crisis. The umbilical thread of the preceding pitch argument, for instance, snaps at the point of eruption. The bass line to those magma-like collisions continues to outline the opposition $\mathrm{A}$ to $\mathrm{C}$, before composing out the chromatic descent from $\mathrm{C}$ to $\mathrm{A}$ that was traced by the refrains' capsules of 'toi' (this key thematic idea having originally been heard, en miniature, in the first episode's evocation of 'la nuit' at Fig. 6); the upper voice topping these sonorities, in turn, traces a chromatic ascent to $\mathrm{C}$. The mutual attainment of these reference pitches, however, is the trigger for an eruption rather than a celebratory gesture of synthesis. The climax chord at Fig. 96 (see Ex. 1 above) is a clear example of the obliterating power of such sounds in Lutosławski's music. There is no 'classicist' developmental fealty here to the i.c. pairings $1+3$ or $2+5$, associated with $A$ and $C$ respectively. Instead, i.c.s 1, 2, 3, 4, 5 and 7 are stacked in a fourteen-note tower of fff dissonance lent sonorous punch by the triadic formulations underpinning the sonority's voicing. This is not just a rhetorical firework, however - and even if it was, its effects could hardly be described merely as 'middlebrow' titillation. Its abnegation of intervallic and pitch-centric identity can be heard as a shattering of the music's discourse on the possibility of quasi-symphonic plotting in late-modern art - and as the death spasm marking the terminative result of the 'toi' refrain's chromatic poisoning. 
Yet this culmination - or anti-culmination - is not the music's conclusion. Instead, Lutosławski's peak of acceptably unacceptable modernism kicks open one of Casken's windows onto new and imaginary worlds, revealing the piece's final heterotopian space, within which the persona's search for 'toi' and hope in 'la nuit' are again reconfigured. In the climax's aftermath, in a reversal of the harmonic accommodations of the central dreamscape (where the realm of 'toi', it will be recalled, entertained the pitch-class A), 'la nuit' is reiterated on C (if not 'in $\left.C^{\prime}\right)$. The subtle coup of this moment, and its role as a staging post rather than a synthesizing destination, is symbolized by Lutosławski's unnecessary but suggestive enharmonic respelling of $\mathrm{C}$ as $\mathrm{B} \#$ in the score, as if a quasi-tonal notational gesture is required to permit the 'modulation' to the ending's series of ravishing, and structurally novel, sonorities - and also to erase the stains of the past. The intricately constructed seventeen-note string texture at Fig. 97 (see again Ex. 1) explores the i.c. $2+3$ pairing - i.c. 3 being the other (inner) intervallic component of the 'toi' [0257] key idea, and an intervallic colour hinted at by the voice's occasional focus on minor thirds in the tranquillo and elsewhere. The piece then finds the heart of 'toi' 'dans la nuit', not by centring on $A$ or $C$ with i.c. pairing $1+3$ or $2+5-$ as one might expect of a more conventional form of resolution - but instead by focussing on that other benchmarking pitch-class, E, after the quasi-dominant preparation of a focus around B. And while one might still be tempted to hear a so-near-and-yet-so-far neo-tonality here, and thus a trace of the constitutive subject fracturing yet again as the persona's dreaming self reawakens, one could alternately entertain the notion that daybreak, and the coda's triumphant turning inside out of Les espaces du sommeil's compositional 
materials and symbolic preoccupations, forges a solution that goes beyond the utopian fakery of a neo-classicist synthesis decked out in modernist garb. Lutosławski's coda is the sound of heterotopia 'dans le jour aussi'.

\section{Heterotopias, Modernisms, Contexts}

The conception of a modernism characterized primarily by representations of alienation, nostalgia, ruin, loss and mourning, and as embodied by the acceptably unacceptable musical styles forming the tradition Cross narrates from Mahler to Birtwistle, becomes problematic only if prescriptively assumed to be the sole authentic path of musical modernism. Cross suggests nothing of the sort, of course, although (as is the case in readings of modernist music from Adorno to Cross and beyond) neither does he feel the need to apologize for the value he locates in this branch of the tradition. Nor should he. However, as suggested by the theoretical trajectory of Foucault's thinking in The Order of Things - which embarks from his first description of heterotopia - musicology's canonic myth of modernist authenticity is an episteme, or at least an episteme en miniature. In Paul Jorion's words, an episteme is 'a mode of representation combining the meaningful questions as to knowledge and the legitimate ways of answering them,; ${ }^{62}$ it helps one make sense of the world at a particular time and in a particular place, but with the drawback that contributions to such discourses argue for their position while simultaneously foreclosing counterarguments, i.e., the stark impossibility of thinking that. To discipline knowledge in this manner is

${ }^{62}$ Paul Jorion, 'Foucault, Paul Michel' in Justin Wintle, ed., The Concise New Makers of Modern Culture (Routledge: London, 2009), 253. 
simultaneously to punish those who do not fit the bill, as in Birtwistle's swipe at ‘easy’ Lutosławski.

One could respond to this by arguing that it is possible to value aspects of Lutosławski's music within the dominant episteme. This essay has indicated approaches to doing so, and one could go further down this path, for instance by investigating aspects of the composer's own 'rhetoric of autonomy' ${ }^{\text {63 }}$ and the extent to which his public statements sought to position his music and ideas within modernism's mythic traditions. But there are other narratives biographical, historical, socio-political and aesthetic - to which Lutosławski's music pertains, and which invite one to consider variant forms of authenticity, not least in light of revisionist scholarship on music and modernism which diversifies what one might mean when one speaks of musical modernism. ${ }^{64}$ As Cross has

${ }^{63}$ Charles Wilson, 'György Ligeti and the Rhetoric of Autonomy', TwentiethCentury Music 1/1 (2004), 5-28.

64 See, for example, Geoffrey Chew, 'Introduction: The Geography of Modernism: Reflections on the Theme "New Music for a New Europe"', Ideology, Theory, and Practice (Praha: KLP, 2007 [2003]), 7-14; Björn Heile, ed., The Modernist Legacy: Essays on New Music (Farnham: Ashgate, 2009); Laura Tunbridge et al., 'Round Table: Modernism and its Others', Journal of the Royal Musical Association 139/1 (2014), 177-204 (the round table includes Chowrimootoo's paper); and Harper-Scott, The Quilting Points of Musical Modernism. 
recently suggested, by way of example, more variegated conceptions of modernism could, for instance, become profitably 'local' ${ }^{65}$

In spite of the difficulty of many of their life experiences, some recent Central/East European artists can be argued to have maintained - enshrined even - spaces for hope, consolation, dreaming and beauty in carefully structured relationships to their art's more pessimistic expressions. Consider the following three statements. One is by Lutosławski; one is by Krzysztof Kieślowski, another renowned Polish artist who lived through the decades in which Lutosławski produced his modernist compositions, and whose films sought to extend the language of television and cinema in order to evoke alternative modes of being; and one is by a wallpapering Russian woman. Interviewed by a BBC film crew that had managed to enter the Soviet Union in 1981 and secretly film scenes of everyday life, the latter expresses, in the opinion of filmmaker Adam Curtis, 'the emptiness and disillusion that was spreading through all levels of society' in the Soviet bloc at this time, and yet in 'in a beautiful and touching way' hinting at a continuing need for, and creation of, more hopeful experiences.

Lutosławski: ‘Creative artists live a sort of double life, because several hours a day they are in another world, in a world that has (apparently, at least) nothing in common with the external world in which we live. I think this ideal world is the world of our dreams, of

${ }^{65}$ Jonathan Cross, 'From the Technical to the Aesthetic: Analysing Modernism', keynote lecture at the Eighth European Music Analysis Conference (Leuven, September 2014). 
our wishes, of our notion of ideal... And our task, our role, our mission, is to make this ideal world accessible to those who are not accessed to it... . 66

Kieślowski: 'Our descriptive tools had been used for propaganda purposes... Outside Poland, you don't know what it means to live in a world without representation. ${ }^{67}$

Panorama interviewer and wallpapering Russian: Interviewer - 'If you had a wish, what would it be?' Wallpaperer - 'What?' Interviewer - 'A wish, a dream?' Wallpaperer - 'A dream... What can I say? I wouldn't even know what to tell you. ... I don't wish for anything. I don't have any dreams, [and] even if I did, they wouldn't come true. I used to dream, to make plans, but nothing worked out and now I don't believe anymore. I won't think about it anymore, and I won't dream again. ${ }^{68}$

${ }^{66}$ Quoted in Charles Bodman Rae, The Music of Lutosławski, $3^{\text {rd }}$ edn (London: Omnibus Press, 1999), 178.

${ }^{67}$ Statement from documentary I'm So-So (Wierzbicki, 1995), quoted in María Elena de las Carreras-Kuntz, 'Kieslowski, Krzysztof', in lan Aitken, ed., The Concise Routledge Encyclopedia of Documentary Film (Abingdon: Routledge, 2013), 487.

${ }^{68}$ Clip embedded in Adam Curtis, 'The Years of Stagnation and the Poodles of Power' (19 January 2012), 
The woman's experience of the fate of her inner life in Russia at the fagend of Soviet Communism recalls Foucault, writing at the end of 'Different Spaces', where he envisages a world without ships and thus without heterotopias: 'dreams dry up, espionage takes the place of adventure, and the police that of the corsairs' ${ }^{69}$ Her comments should not, naturally, be read as totemic of all Russian experience in this period, still less of Polish experience - a country in which life differed in sharp and subtler ways from Russian life under communism. Kieślowski and Lutosławski's comments nevertheless imply the desire of some artists in socialist Poland to fashion cultural texts within which spaces to dream might be experienced alongside reflections on the more negative aspects of life - as in films including Kieślowski's Blizna ('The Scar', 1976), Amator ('Camera Buff', 1979) and Dekalog series (1989), or compositions such as Lutosławski's Les espaces du sommeil.

It might even be possible to extend such discussions to forms of domestic display (not least wallpaper choices) in private Polish homes. As David Crowley writes in Warsaw, his evocative study of public and private spaces in Lutosławski's home city post World War II, while Westerners might have imagined Warsaw to be 'a place of drab and unrelenting concrete buildings' forming 'an index of the grey "reality" of late Eastern Bloc socialism' (David Bowie and Joy Division evoked Warsaw 'as the site of a prolonged catastrophe'), it was http://www.bbc.co.uk/blogs/adamcurtis/posts/the_years_of_stagnation_and_th (last accessed 4 February 2014).

${ }^{69}$ Foucault, 'Different Spaces', 285. 
not only the tempo of life in Warsaw that felt different for most citizens (not so much 'prolonged catastrophe' as time endlessly dragging by while one queued). ${ }^{70}$ Contradicting the Party's public discourse regarding homes (they were not meant to become 'sites of consumption where commonplace things were appropriated into personal, "interior" spaces of memory and association'), ${ }^{71}$ Varsovians from peasants to the intelligentsia enacted a 'creative occupancy of the standard flat'; avant-garde theatre company Teatr Osobny Trzech Osób (The Individual Theatre of Three Individuals) even staged productions in its members' apartments. ${ }^{72}$ Nonetheless, such acts may also have sharpened people's awareness of the problems of their surroundings. 'The neglect and blankness of common spaces', Crowley suggests, 'was all the more apparent in Warsaw because it was in sharp contrast to the careful production of domesticity' - not least in the case of Lutosławski's tasteful yet chic, and eminently Ty $i$ Ja-worthy, private home on Warsaw's ul. Śmiała, to which his family had escaped from a crowded block of flats by the time he composed Les espaces. ${ }^{73}$ The consolations of these private spaces, and the manner in which they implicitly critiqued and

${ }^{70}$ David Crowley, Warsaw (London: Reaktion Books, 2003), 14, 9.

${ }^{71}$ Crowley. Warsaw, 153.

${ }^{72}$ Crowley, Warsaw, 163-64, 171-73.

${ }^{73}$ Upmarket style magazine Ty i Ja (You and I) had a 'My Home is My Hobby' feature that regularly focussed on the dwellings of prominent artists. In his forthcoming study of Lutosławski's Cello Concerto (1969-70), Adrian Thomas documents Lutosławski's enthusiastic sourcing of high-quality carpet from the UK to furnish his new home (specifically from Gamages in Holborn, London). 
revealed as illusory the governing rationale of their encapsulating emplacements, calls to mind Foucault's sixth principle - a heterotopia's potential functions in relation to all remaining space.

Did other Polish musicians repaper the concert halls in ways that might begin to sound heterotopian in light of this essay's discussions? Lisa Jakelski has offered a provocative assessment of the impact of Henryk Górecki's exuberantly avant-garde Scontri in Poland in 1960. 'Wholly adhering to the aesthetic mandates of neither East nor West,' Jakelski argues, 'Górecki [became] a sign of Polish difference. ${ }^{, 74}$ Jakelski traces Scontri's transformation of spaces at the 1960 Warsaw Autumn festival both analytically and through reception history. From the triangular layout required for the piece's massive forces to Górecki's chomping up of serial techniques to emancipate gesture and sonority, and then out into the orchestral performance's transformation of the physical space of the concert hall and the embodied experiences of those listening ('The walls shook, the audience went deaf, and my jaw hit the floor ${ }^{75}$ one critic wrote pejoratively of hearing Scontri's Warsaw premiere), the music, to recall Johnson on Foucault, clearly disrupted the usual patterns of music and thought, 'unhinging the familiar'. ${ }^{76}$ The sound created twenty years later by Kontrola W. (short for Kontrola Władzy, 'Control of Power'), a Polish post-punk band active in the early 1980s, offers another potential heterotopia. Their leader, Darek Kulda, spoke of

${ }^{74}$ Lisa Jakelski, 'Górecki's Scontri and Avant-Garde Music in Cold War Poland', The Journal of Musicology 26/2 (2009), 213.

75 Jerzy Waldorff, quoted and translated in Jakelski, ibid., 222.

${ }^{76}$ Johnson, 'Ways Forward', 4. 
deciding 'to create a band whose music would be unclassifiable, neither rock, nor jazz, nor nothing'; their subsequent performances, Agata Pyzik claims, created '[a]n out-of-tune, sick, broken rockandroll' forming unique musical spaces (at gigs, through tape recordings circulated between friends) that lent a Polish tincture to the 'typical disillusioned subjects' (control of the state, media brainwashing, erasure of the self) of punk and post-punk. ${ }^{77}$

To elaborate on these suggestions, it would be necessary to measure the relevant musical texts against the criteria for identifying cultural representations of heterotopia outlined in the second section of this essay. Such discussions lie beyond the remit of the present study. By returning to Lutosławski, however, and drawing conclusions about the extent to which his music's technical and symbolic content measures up against Foucault's six principles, it is possible to demonstrate how such arguments might proceed. The ensuing discussion therefore moves between the socially symbolic and musically specific in Les espaces du sommeil.

Foucault's first principle claims that heterotopias are a universal feature of human societies, and that experiences of crisis and deviance motivate their existence; his second principle argues that heterotopias always perform unique functions in their encapsulating society; and his sixth suggests that heterotopias have two main functions in relation to all remaining space - revealing the illusory nature of the heterotopia's surroundings, or providing consolation through 'a different space... as perfect, as meticulous, as well-arranged as ours is

${ }^{77}$ Agata Pyzik, Poor but Sexy: Culture Clashes in Europe East and West (Alresford, Zero Books, 2014), 267-69. 
disorganized, badly arranged, and muddled'. This essay has outlined various contexts within which one might argue that Lutosławski's heterotopias are heterotopias of crisis. In terms of compositional argument, they literally occur at points of syntactical crisis. The two longest heterotopias in Les espaces, for instance, occur after the junkyard chromaticism preceding the central tranquillo and in the coda that follows the obliteration of developmental discourse at the climax of the piece. Their soothing sensuousness and audibly meticulous organization offer respite from the ferocity of their preceding and encapsulating materials; more subtly, they disclose alternative forms of beauty to the (more conventional and ultimately tragic) modernist enactment of a 'stunned and dispirited' remembrance, in Eagleton's words, of more stable systems of meaning now past. To which crisis, however, or even crises, is the music symbolically responding? With Lutosławski, one is spoilt for choice. If one believes it would be distasteful to relate his music's symbolic resonances to the composer's own experiences of trauma, violence and loss, yet reductive merely to consider the music as an abstraction of some universal human need, their specific meaning might be sought in relation to broader issues in Polish society in the mid-1970s such as those outlined above in relation to social and domestic spaces. Alternatively, it is possible to consider Lutosławski's heterotopias as a personal musical response to Jameson's 'grand modernist thematics of alienation, anomie, solitude, social fragmentation, and isolation'.

Foucault's fifth principle relates to access: a certain number of gestures must be performed before access to a heterotopia can be achieved. His fourth concerns temporal discontinuity: heterotopias are formed through some kind of 
absolute break with time. The point of syntactical crisis noted above at the climax of Les espaces is the collapse of a longer-range process of thwarted teleology; one hears such collapses often in Lutosławski works of the late 1950s and after. Typically, Lutosławski creates music in which a plot of events seems to be heading along familiar trajectories of musical development until, at the point of crisis, the developmental effort and, indeed, entire mode of goal-directed compositional discourse collapses. For sure, many earlier musical plots fail to achieve musical goals they have hitherto established as desirable - a key marker of musical tragedy. Lutosławski's tragedies are modernist, however, in the sense of Eagleton's tragic modernism: it is not just a positive outcome that is lost, but also the possibility of meaning itself within the terms of a hitherto established system. And yes, certain gestures have to be performed en route to a Lutosławskian vanishing point/heterotopian entry point. One might reasonably expect to hear escalating intensity in the form of a macrorhythmic accelerando and textural accrual, orchestral pauses heightening the tension, then a brutal climax in which pugilistic sonorities shatter the music's sense of time and syntax with a twelve-note, ad libitum eruption. Sometimes, this is followed by a period of numbed stasis and lament (as in, for instance, the String Quartet) - anti-climactic gestures that fit into the dominant modernist episteme with appropriate solemnity. Particularly in the late 1960s and 1970s, however, Lutosławski tends to follow rupture with heterotopias in which pulsation is suspended and narrative time yields, not to numbed and dispirited stasis, but to a kind of zero-gravity warmth: a musical flotation tank in which to escape, reflect, and even heal. 
Discussing how heterotopias must be 'interruptive', ${ }^{78}$ Johnson cites De Cater and Dehaenes utilization of Foucault's concept when categorizing spaces in ancient Greek cities, and their theorizing of heterotopian emplacements in 'sacred or cultural area[s] for religion, the arts, sport and leisure' ${ }^{79}$ These spaces of 'free time' interrupt continuity, break entrenched binaries, create centres of play or 'a creative clearing' providing a haven or sanctuary, the purposes of which cannot be reduced to brute economic imperatives. Heterotopias thereby 'disrupt the usual patterns and categories of thought, unhinging the familiar': 'they seem to reflect or gather in other spaces and yet unsettle them at the same time' ${ }^{80}$ As Foucault explained, this unsettling is partially achieved by suspending, neutralizing or reversing a set of relations more typical of the encapsulating emplacements to which heterotopias are, through such processes, related. A heterotopia also unhinges the familiar, however, by enacting Foucalt's third principle: the juxtaposition, or even superimposition, of the incompatible.

The end of Les espaces evokes its dream of difference through layerings of notionally incompatible elements. Stylistically, diatonic, modal and chromatic

${ }^{78}$ Peter Johnson, 'Ways Forward - A disturbing relational concept' (2012), 3. See http://www.heterotopiastudies.com/wp-content/uploads/2012/05/3.3-WaysForward.pdf (last accessed 24 February 2014).

79 Johnson, 'Ways Forward', 4. Johnson cites Lieven de Cauter and Michiel Dehaene 'The Space of Play: Towards a General Theory of Heterotopia' in. Dehaene and De Cauter, eds., Heterotopia and the City (London and New York: Routledge, 2008), 87-102.

80 Johnson, 'Ways Forward', 4. 
modes of pitch organization interlock, as do a range of earlier and later modernist styles. Together they explore tensions between an urge for centricity and a desire for free-floating chromaticism, between stasis and goal-directedness, and between early modernist intimations of exoticism and later modernist gestures of brutality - or what Foucault called 'a whole succession of places that are unrelated to each other, ${ }^{81}$ or at least more typically located in separate times and/or spaces. In terms of the relationship of the coda to the piece's earlier materials, the closing heterotopia also evades commentary on the main thematic arguments of the preceding materials - the argument that collapses at the point of rupture - instead alighting on, and altering, hitherto unexplored elements of the music's key ideas to fashion new sonorities and lines. C transforms into B\#; the cushion of strings beneath the miraculously returning baritone, and its unfurling song, are rendered from intervallic parameters of earlier material not yet highlighted by the music (i.c.s 2 and 3). In a similar fashion, hitherto important pitch centres (A and $\mathrm{C}$ ) are eschewed for the closing focus on $\mathrm{E}$; and a gesture that, up until this point in the piece, might merely have signified modernist fragmentation and ruination, is transformed into a hammer-like gesture capable of punching a hole from heterotopia into the light of day.

It thus seems reasonable to claim that, in terms of their expressive, syntactical and symbolic content, certain passages in Lutosławski can be read as heterotopian. More strongly, they create heterotopian experiences for perceivers. These are not as brazenly confrontational as Scontri or Kontrola Władzy; passages like the central tranquillo and aftermath in Les espaces are, in many

${ }^{81}$ Foucault, 'Different spaces', 181. 
ways, their expressive opposites. Yet Lutosławski's compositions' charms and consolations should not deafen one to their test of the moral imagination, any more than their more conventionally authentic modernist gestures should lead one towards facile revisionism. Furthermore, while his heterotopias can clearly be argued to have achieved symbolic resonance in quite specific ways within their original 'local' context, this does not discount the possibility that his music continues to raise challenging questions for quite differently situated historical agents - such as those of us, in Poland and elsewhere, experiencing the social and psychic wounds of the oedipal-capital machine. To enter Lutosławski's 'ideal worlds' is to accept an invitation to reflect on one's realities while envisaging alternative realms in which our dreams of difference might be experienced dans le jour aussi, i.e., in the 'real world' as well. This is consoling, for sure, but not merely consoling: the consolations seduce one into asking why more of his music, and why more of life itself, cannot also be so beautiful.

One receives this provocation time and again in Lutosławski's finest pieces. To consider only the sequence of milestones with Les espaces at its centre: Livre, the Cello Concerto, Les espaces, Preludes and Fugue (1970-72) and Mi-parti (1975-76) all feature such passages, and the differing treatment of heterotopia in each is crucial to each work's expressive specificity. Compare and contrast, for instance, the endings of his Fugue and Mi-parti-exquisite moments that are, respectively, wrenched away and permitted to linger. These distinctive (and distinctively) heterotopian emplacements might be said to embody Foucault's 'expression of pleasure in variety, the destiny and energy of aesthetic 
and intellectual projects' ${ }^{82}$ The symbolic potency of Lutosławski's most provocative compositions, in turn, may approach Foucault's vision of the role of the intellectual: 'to excavate one's own culture in order to show the contingency of power and to find spaces for creativity and resistance. ${ }^{83}$ One thing is certain. A hundred years after Lutosławski's birth, and twenty years after his death, our need for such spaces, and thus for Lutosławski, will not be ending anytime soon.

${ }^{82}$ From Edward Said's obituary for Foucault, 'Michel Foucault, 1926-84', in J. Arac, ed., After Foucault: Humanist Knowledge, Postmodern Challenges (Rutgers: Rutgers University Press, 1988); quoted in Stanley Cohen and Laurie Taylor, Escape Attempts: The Theory and Practice of Resistance to Everyday Life, $2^{\text {nd }}$ edn (London: Routledge, 1992), 28.

${ }^{83}$ Cohen and Taylor, Escape Attempts, 29. 


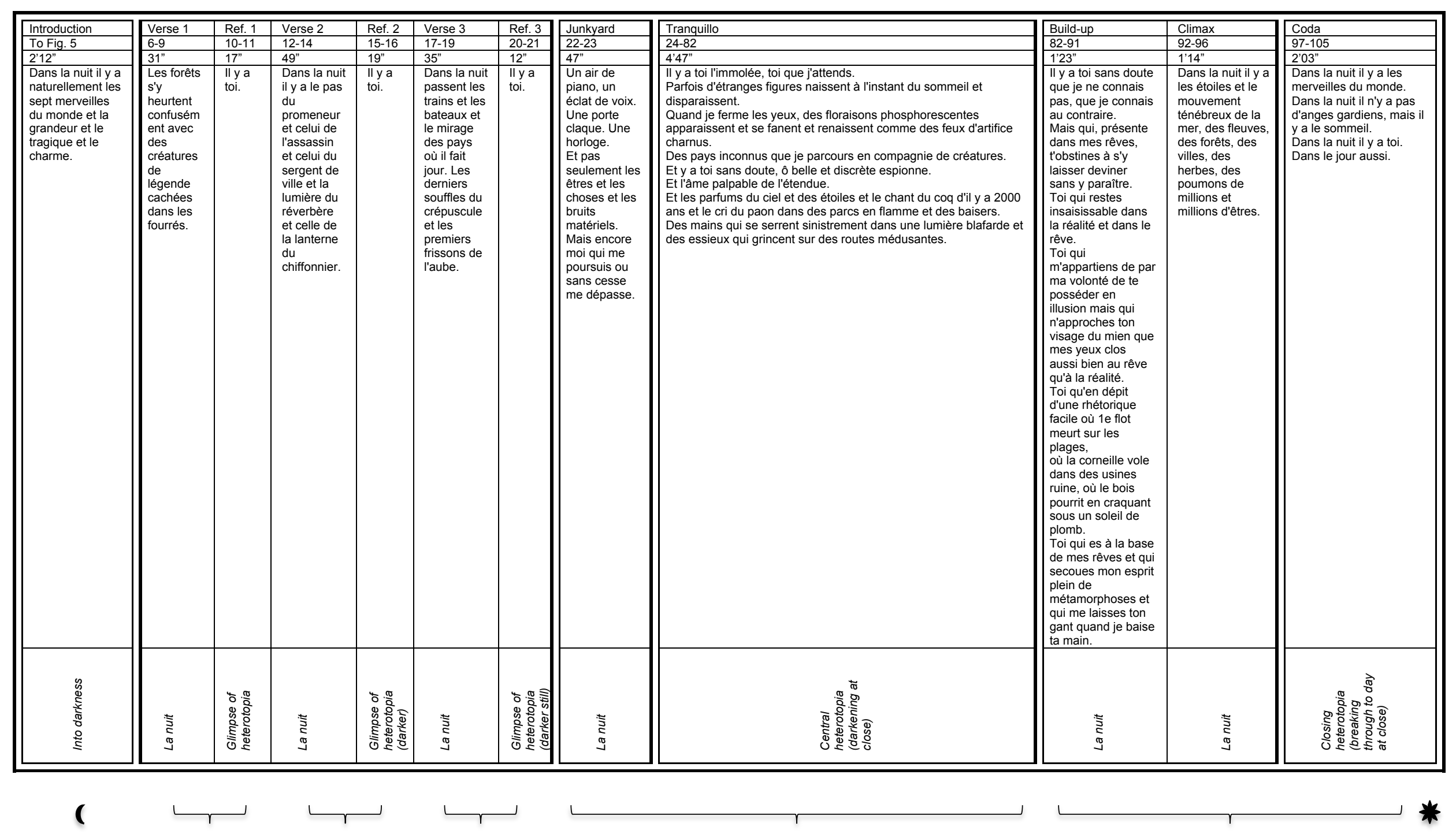

